OPEN ACCESS

Edited by:

Fabrizio Mattei,

Istituto Superiore di Sanità (ISS), Italy

Reviewed by:

Limin Zheng,

Sun Yat-sen University, China

Douglas Mc Clain Noonan,

University of Insubria, Italy

*Correspondence: Julia Kzhyshkowska

julia.kzhyshkowska@

medma.uni-heidelberg.de

Specialty section: This article was submitted to Cancer Immunity and Immunotherapy, a section of the journal

Frontiers in Immunology

Received: 29 May 2019 Accepted: 28 November 2019 Published: 22 January 2020

Citation:

Kzhyshkowska J, Larionova I and Liu T (2020) YKL-39 as a Potential New

Target for Anti-Angiogenic Therapy in Cancer. Front. Immunol. 10:2930 doi: 10.3389/fimmu.2019.02930

\section{YKL-39 as a Potential New Target for Anti-Angiogenic Therapy in Cancer}

\author{
Julia Kzhyshkowska ${ }^{1,2,3 *}$, Irina Larionova ${ }^{3,4}$ and Tengfei Liu ${ }^{1}$ \\ ${ }^{1}$ Medical Faculty Mannheim, Institute of Transfusion Medicine and Immunology, University of Heidelberg, Mannheim, \\ Germany, ${ }^{2}$ German Red Cross Blood Service Baden-Württemberg-Hessen, Mannheim, Germany, ${ }^{3}$ Laboratory of \\ Translational Cellular and Molecular Biomedicine, National Research Tomsk State University, Tomsk, Russia, ${ }^{4}$ Cancer \\ Research Institute, Tomsk National Research Medical Center of the Russian Academy of Sciences, Tomsk, Russia
}

YKL-39 belongs to the evolutionarily conserved family of Glyco_18-containing proteins composed of chitinases and chitinase-like proteins. Chitinase-like proteins (CLPS) are secreted lectins that lack hydrolytic activity due to the amino acid substitutions in their catalytic domain and combine the functions of cytokines and growth factors. One of the major cellular sources that produce CLPs in various pathologies, including cancer, are macrophages. Monocytes recruited to the tumor site and programmed by tumor cells differentiate into tumor-associated macrophages (TAMs), which are the primary source of pro-angiogenic factors. Tumor angiogenesis is a crucial process for supplying rapidly growing tumors with essential nutrients and oxygen. We recently determined that YKL-39 is produced by tumor-associated macrophages in breast cancer. YKL-39 acts as a strong chemotactic factor for monocytes and stimulates angiogenesis. Chemotherapy is a common strategy to reduce tumor size and aggressiveness before surgical intervention, but chemoresistance, resulting in the relapse of tumors, is a common clinical problem that is critical for survival in cancer patients. Accumulating evidence indicates that TAMs are essential regulators of chemoresistance. We have recently found that elevated levels of YKL-39 expression are indicative of the efficiency of the metastatic process in patients who undergo neoadjuvant chemotherapy. We suggest YKL-39 as a new target for anti-angiogenic therapy that can be combined with neoadjuvant chemotherapy to reduce chemoresistance and inhibit metastasis in breast cancer patients.

Keywords: YKL-39, chitinase-like proteins, cancer, angiogenesis, chemotactic activity, tumor-associated macrophages, neoadjuvant chemotherapy

\section{INTRODUCTION}

YKL-39 belongs to the family of Glyco_18-containing proteins composed of chitinases and chitinase-like proteins. Chitinases comprise the Glycosyl hydrolase (GH) 18 family; their name originates from their ability to cleave chitin polymers into oligosaccharides of different sizes and release monosaccharides from the end of chitin polymer $(1,2)$. Chitin is the second most abundant polysaccharide in nature (after cellulose) and is found in the cell walls of fungi and the exoskeletons of crustaceans and insects (3-5). The chitinases are produced by the lower life forms as a defense mechanism against infection with chitin-containing organisms $(6,7)$. Mammals cannot synthesize chitin, but several chitinases and chitinase-like proteins have been identified in rodents and in humans. In humans, two functional chitinases-Acidic Mammalian Chitinase (AMCase) and Chitotriosidase (CHIT1)-have been found. AMCase is induced by IL-13 and is found in 
A
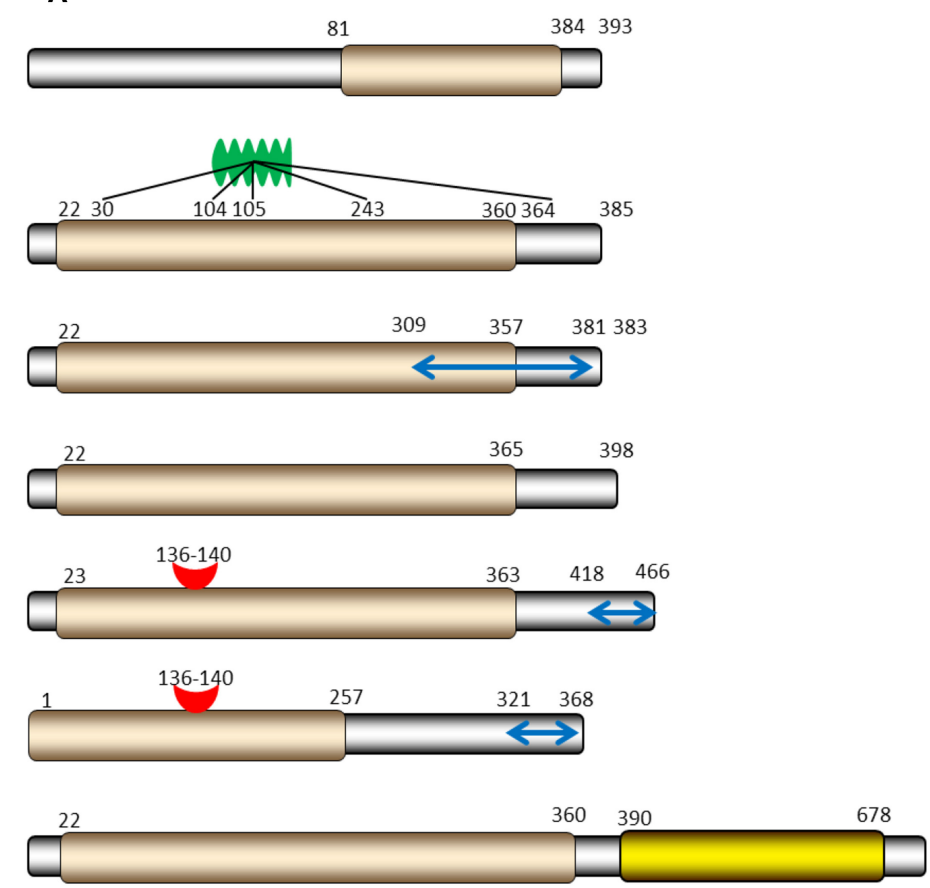

SI-CLP

YKL-39

YKL-40

YM1

Chitotriosidase

AMCase

Oviductin

Glyco_18domain $\longleftrightarrow$ Chitin binding domain O-glycosylated region

Catalytic site Chitin binding groove

B

$$
\begin{gathered}
\text { FDGIDIDWEYP } \\
1-186-\text { FDGFVVEVMNQ-393 } \\
1-131-\text { FDGLDVSWIYP-385 } \\
1-131-\text { FDGLDLAWLYP-383 } \\
1-131-\text { FDGLNLDWQYP-398 } \\
1-131-\text { FDGLDLDWEYP-466 } \\
1-131-\text { FDGLDFDWEYP-368 } \\
1-132-\text { FDGLDLFFLYP-678 }
\end{gathered}
$$

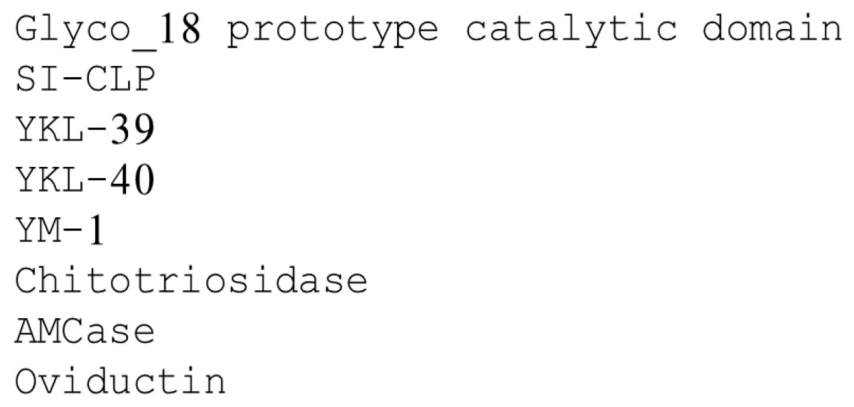

FIGURE 1 | Structure of mammalian chitinases and chitinase-like proteins. (A) Domain organization of Glyco_18-containing proteins. (B) Critical amino acids in catalytic sites of mammalian Glyco_18-containing proteins (12), Copyright by de Gruyter.

allergic inflammations such as asthma (8, 9). Chitotriosidase is expressed by phagocytic cells and is a biomarker for Gaucher's disease, a lysosomal storage disease that involves the dysfunctional metabolism of sphingolipids $(10,11)$.

Chitinase-like proteins (CLPs), as well as chitinases, possess Glyco_18 domains, but they lack enzymatic activity (12). In mammals, the following CLPs have been identified: YKL-40 (13), YKL-39 (14), SI-CLP (15), YM1, and YM2 (16). Of these, YKL-39 is present only in humans but absent in rodents, while YM1 and YM2 are only present in rodents (12).
CLPs lack enzymatic activity due to the substitution of the critical catalytic residue (glutamic acid) at the end of the DxxDxDxE conserved motif with either leucine, isoleucine, or tryptophan (Figure 1) (12).

The sugar-binding properties of CLPs are attributed to the Glyco_18 domain of CLPs (Table 1). Lectin properties define the interactions of CLPs with glycoproteins on the cell surface and with specific carbohydrate molecules in the extracellular matrix. For YKL-40, lectin properties have been identified to be critical for its interaction with syndecan- 1 and $\alpha v \beta 3$ 
TABLE 1 | Lectin properties of CLPS.

\begin{tabular}{llll}
\hline CLP & Carbohydrate-binding & Method of analysis & References \\
\hline YKL-39 & $\begin{array}{l}\text { Chitooligosaccharides, } \\
(\text { GlcNac)5, and (GlcNac)6 }\end{array}$ & $\begin{array}{l}\text { Glycan array screen } \\
\text { and intrinsic tryptophan } \\
\text { fluorescence } \\
\text { Isothermal titration } \\
\text { calorimetry (ITC) }\end{array}$ \\
Chitooligosaccharides & $\begin{array}{l}\text { Affinity chromatography } \\
\text { and surface plasmon } \\
\text { resonance }\end{array}$ \\
Tyl-40 I collagen & Chitooligosaccharides & $\begin{array}{l}\text { Protein X-ray } \\
\text { crystallography }\end{array}$ \\
& $\begin{array}{l}\text { Western blotting } \\
\text { (GlcNac)5 and (GlcNac)4 } \\
\text { Heparin }\end{array}$ & $\begin{array}{l}\text { Heparin affinity and } \\
\text { HPLC chromatograph } \\
\text { Isothermal titration }\end{array}$ \\
calorimetry (ITC)
\end{tabular}

integrin, resulting in the activation of the ERK1/2 pathway and vascular endothelial growth factor (VEGF) production in endothelial cells $(25,26)$. Moreover, SI-CLP was shown to bind lipopolysaccharide (LPS) in vitro and thereby to neutralize the toxic effect of LPS on macrophages (23). By applying a glycan microarray, performed at the Consortium of Functional Glycomics, the chitooligosaccharides were identified as the best ligands of YKL-39 (17). Structural analysis demonstrates that YKL-39 interacts with chitooligosaccharides through hydrogen bonds and hydrophobic interactions, and compared with other GH-18 members, YKL-39 has the least extended chitin-binding cleft (18). However, the biological relevance of these interactions is questionable, since chitin is not synthesized by mammals, and the tissue expression of YKL-39 rather precludes contact with chitooligosaccharides as a component of the nutrition or pathogens (17).

\section{YKL-39 IDENTIFICATION AND EXPRESSION IN PATHOLOGY}

YKL-39 was first identified when found to be produced in high amounts by synoviocytes and chondrocytes $(14,27)$ and was suggested as a circulating biomarker for osteoarthritis (OA) $(14,27,28)$. Increased YKL-39 mRNA levels were also detected in the microglia of Alzheimer patients (29). The detection of YKL-39 in cerebrospinal fluid was suggested to be a potential prognostic biomarker in the early stage of multiple sclerosis $(30,31)$. Also, YKL-39 mRNA levels were significantly increased in the hippocampus in simian immunodeficiency virus encephalitis (SIVE) and HIV encephalitis (HIVE) (32). These data suggested the role of YKL-39 in both neurodegeneration and chronic inflammatory diseases of the brain. We have recently identified that YKL-39 is expressed in human breast cancer (33), and these data are discussed in the context of the role of CLPs in tumor progression and response to therapy in the following paragraphs.

\section{BIOLOGICAL ACTIVITIES}

Biological activities of chitinase-like proteins related to tumor progression include chemotactic activity, growth factor activity, induction of cytokine secretion, and stimulation of angiogenesis. YKL-39 was identified to combine monocyte chemotactic and pro-angiogenic activities (33), and these biological activities will be discussed in our review.

\section{CHEMOTACTIC ACTIVITY}

Several chitinase-like proteins were demonstrated to have chemotactic activities. YM1 was first identified as eosinophil chemotactic protein (ECF-L) (34). YM1 attracted T lymphocytes and bone marrow polymorphonuclear leukocytes in vitro and induced selective extravasation of eosinophils in a mouse model (34). Microglia-secreted YM1 was suggested to be involved in eosinophilic meningitis and meningoencephalitis caused by Angiostrongylus cantonensis infection (35). YM1 and YM2 were strongly induced in a mouse model for proliferative dermatitis characterized by the accumulation of eosinophils in the skin (36).

Human YKL-40 was reported to have chemotactic activity toward different cell types. Nishikawa et al. showed that YKL-40 is associated with vascular smooth muscle cell (VSMC) migration and invasion into the gelatinous matrix (22). YKL-40 expressed in human colon cancer SW480 cells enhanced the migration of human monocyte-like THP-1 cells and human umbilical vein endothelial cells (HUVEC). The expression of YKL-40 was associated with macrophage infiltration and micro-vessel density (MVD) in the tumors of human colorectal cancer patients and in a xenograft mouse model (37). YKL-40 was also found to contribute to the migration of bronchial smooth muscle cells indirectly by inducing the expression of IL-8 (38).

We have recently demonstrated that purified YKL-39 strongly induces the migration of freshly isolated human CD14+ monocytes (Figure 2) (33). YKL-39 was active at the concentration of $100 \mathrm{ng} / \mathrm{ml}$ corresponding to the biologically active concentration of YKL-40, $90.3 \pm 8.2 \mathrm{ng} / \mathrm{ml}$, in patients with OA (39). After $3 \mathrm{~h}$ of migration, the effect of YKL-39 was comparable to the effect of the major monocyte chemotactic factor CCL2 if used at the same concentration. Monocytes are intensively recruited into growing tumors by chemotactic factors secreted by tumor cells and stromal cells in the tumor microenvironment, where both tumor-associated macrophages (TAMs) and cancer cells serve as sources of chemotactic factors such as CCL2 $(40,41)$. Monocytes differentiate in the tumor tissue into tumor-associated macrophages, which are key inducers of the angiogenic switch (42). The strong chemotactic activity of YKL-39 makes it an attractive candidate to consider as a target to reduce monocyte recruitment into the tumor tissue. 


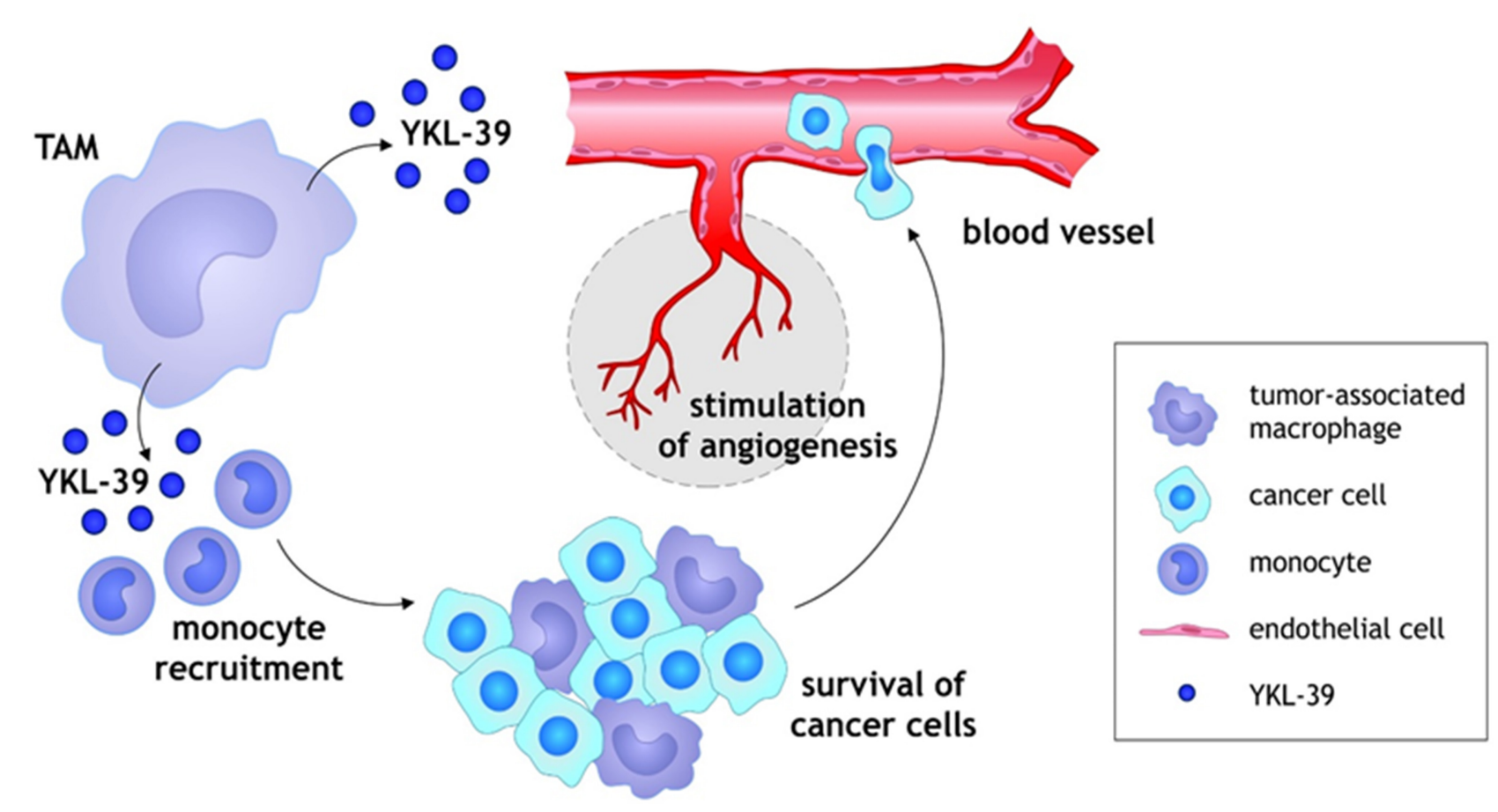

FIGURE 2 | Schematic illustration of YKL-39 activity in cancer. Monocytes are recruited into growing tumors by chemotactic factor YKL-39 secreted by TAMs in the tumor microenvironment, where TAMs support the survival and growth of cancer cells. Monocytes differentiate in the tumor tissue into TAMs, which are key inducers of the angiogenic switch. YKL-39 possesses pro-angiogenic activity and causes stimulation of angiogenesis that can lead to the intensive intravasation of cancer cells to the blood vessels.

\section{ANGIOGENESIS}

YKL-39 was identified by us as a strong pro-angiogenic factor in vitro. Tumor angiogenesis is a crucial process for supplying rapidly growing tumors with essential nutrients and oxygen (41). Monocytes recruited to the tumor site and programmed by tumor cells are known as TAMs, which are the primary source of proangiogenic factors $(41,43)$. TAMs produce a variety of proangiogenic factors under the hypoxic condition in tumor sites, for example, VEGF, which promotes migration of endothelial cells and macrophages toward tumor areas $(40,44)$.

VEGF is the prototypical proangiogenic factor that induces vascular permeability and increased migration and proliferation of endothelial cells, making it a major target for therapy (45). One of the main anti-angiogenic approaches is to block VEGF using a monoclonal antibody (bevacizumab). Other drugs include VEGF pathway inhibitors such as small-molecule tyrosine kinase inhibitors (sunitinib, sorafenib, pazopanib, regorafenib, lenvatinib, and vandetanib), a soluble VEGF decoy receptor (aflibercept), a human monoclonal antibody against VEGFR-2 (ramucirumab), and others $(45,46)$. Administering bevacizumab in combination with chemotherapeutic agents showed improved survival of patients with colorectal cancer, ovarian cancer, and lung cancer in comparison with chemotherapy alone (46-48). However, there is resistance against anti-VEGF medication, which includes several mechanisms, such as the activation and upregulation of alternative proangiogenic pathways, the recruitment of bone marrow-derived proangiogenic cells, and the adoption of alternative angiogenic mechanisms (45). Several studies have demonstrated TAM accumulation in the tumor mass after chemotherapy and antiangiogenic therapy. Thus, Dalton et al. showed that recruitment of macrophages to the TME after anti-VEGF treatment leads to tumor growth as a mechanism of resistance to therapy but that depletion of macrophages inhibited tumor growth and improved the survival of tumor-bearing mice (49). The vascular disrupting agent combretastatin A4-P causes the increased production of CSF-1, CCL2, and CXCL12 that increases monocyte recruitment and TAM accumulation in tumor sites (50). In mouse mammary tumors, chemotherapy increased the expression of CSF-1 by tumor cells, followed by the recruitment of macrophages (51). Thus, chemotherapy and anti-VEGF therapy have disadvantages such as TAM accumulation and treatment resistance, and additional new therapeutic approaches need to be developed.

Chitinase-like protein YKL-40 has already been shown to be involved in tumor angiogenesis in several studies. It was reported that gp38k (porcine homolog protein of YKL-40) promotes the migration and spreading of VSMCs in vitro (22). The expression of YKL-40 in MDA-MB-231 breast cancer cells and HCT-116 colon cancer cells is also associated with tube formation in an extensive angiogenic phenotype mouse model (26). Recombinant YKL-40 protein was also found to induce angiogenesis of vascular endothelial cells in vitro (52). A correlation between blood vessel density and YKL-40 expression has also been observed in 
human breast cancer patients (53). The YKL-40-induced proangiogenic effect was VEGF-independent, suggesting that YKL40 and VEGF individually promote endothelial cell angiogenesis (26). However, a long-term blockade of VEGF may result in angiogenic compensative tumor cell activities by inducing YKL40 (54). It is most likely that blockade of one angiogenic factor induces the expression of other potent angiogenic factors to maintain tumor vascularization.

YKL-39 has a high structural similarity to YKL-40. Therefore, we considered that YKL-39 can act as a pro-angiogenic factor in cancer. We have performed tube formation assay using HUVEC cells and found that YKL-39 exerts a strong pro-angiogenenic effect through direct activation of vascular endothelial cells (Figure 2). Recombinant YKL-39 at a concentration of $100 \mathrm{ng} / \mathrm{ml}$ significantly induced tube formation in HUVEC cells in vitro (33). This data indicated that YKL-39 can directly induce angiogenesis and that YKL-39-expressing TAMs can serve as a source of angiogenic factors in the tumor microenvironment.

\section{MACROPHAGES ARE A MAJOR SOURCE OF CHITINASE-LIKE PROTEINS}

Pathological programming of macrophages is crucial for the development of major types of life-threatening disorders, including cancer and cardiovascular and neurodegenerative disorders (55-59). Macrophages regulate intratumoral immune responses and the progression of atherosclerosis by the secretion of cytokines, growth factors, enzymes, and extracellular matrix proteins $(41,55,60)$. Two major directions of macrophage polarization are known: pro-inflammatory M1 macrophages with antitumor properties and anti-inflammatory M2 macrophages with pro-tumor functions. In most solid tumors, macrophages are represented by the M2 phenotype, which supports tumor growth, angiogenesis, and metastatic spread $(61,62)$. Macrophages serve as a major source of all murine and human chitinase-like proteins (Table 2). However, the expression of YKL-40 is not restricted to macrophages (TAMs) and has been found in human small cell lung cancer (63), microglia from Alzheimer's disease patients (29), and other cell types. The expression of SI-CLP was detected in peripheral blood mononuclear cells from rheumatoid arthritis (RA) patients (68).

Elevated levels of YKL-39 gene expression were detected in microglia of Alzheimer's patients (29). In in vitro experimental models, expression of CLPs depends on the activation state of macrophages (M1 or M2). YKL-40 expression is elevated during the differentiation process of human macrophages, and macrophage differentiation factors GM-CSF or M-CSF have been shown to induce YKL-40 expression $(65,70)$. It was identified that in human monocyte-derived macrophages, IFN$\gamma$ and LPS are strong inducers of YKL-40 gene expression $(15,67)$. In contrast, expression of SI-CLP is induced by IL-4 and dexamethasone on both the mRNA and protein levels in human monocyte-derived macrophages (15). YKL-39 expression is strongly induced by TGF-beta, an essential regulatory cytokine of the tumor microenvironment (33).
TABLE 2 | Expression of chitinase-like proteins in macrophages.

\begin{tabular}{|c|c|c|c|}
\hline CLP & Macrophage type & Method of analysis & References \\
\hline \multirow[t]{8}{*}{ YKL-40 } & $\begin{array}{l}\text { Human primary } \\
\text { monocyte-derived } \\
\text { macrophages stimulated } \\
\text { by IFN- } \gamma\end{array}$ & RT-PCR & (15) \\
\hline & $\begin{array}{l}\text { Microglia in Alzheimer's } \\
\text { disease patients }\end{array}$ & RT-PCR & (29) \\
\hline & $\begin{array}{l}\text { Human peritumoral } \\
\text { macrophages and murine } \\
\text { lung macrophages }\end{array}$ & RT-PCR & (63) \\
\hline & $\begin{array}{l}\text { Human macrophages in } \\
\text { pulmonary } \\
\text { sarcoid granulomas }\end{array}$ & $\begin{array}{l}\text { Immunohistochemical } \\
\text { staining }\end{array}$ & (64) \\
\hline & $\begin{array}{l}\text { Peritumoral macrophages } \\
\text { in human small cell } \\
\text { lung cancer }\end{array}$ & $\begin{array}{l}\text { Immunohistochemical } \\
\text { staining }\end{array}$ & (63) \\
\hline & $\begin{array}{l}\text { Human primary } \\
\text { monocyte-derived } \\
\text { macrophages stimulated } \\
\text { by GM-CSF or M-CSF }\end{array}$ & $\begin{array}{l}\text { RT-PCR/ELISA } \\
\text { Immunofluorescence } \\
\text { staining }\end{array}$ & (65) \\
\hline & $\begin{array}{l}\text { Murine } \\
\text { pulmonary macrophages }\end{array}$ & RT-PCR/ELISA & (66) \\
\hline & $\begin{array}{l}\text { Human M1 polarized } \\
\text { macrophages stimulated } \\
\text { by LPS and IFN- } \gamma\end{array}$ & RT-PCR & (67) \\
\hline \multirow[t]{4}{*}{ SI-CLP } & $\begin{array}{l}\text { Human primary } \\
\text { monocyte-derived } \\
\text { macrophages stimulated } \\
\text { by IL-4+dexamethasone }\end{array}$ & $\begin{array}{l}\text { RT-PCR/Western } \\
\text { blotting/Immunofluorescence } \\
\text { staining }\end{array}$ & nce \\
\hline & $\begin{array}{l}\text { Murine bone marrow- } \\
\text { derived macrophages }\end{array}$ & $\begin{array}{l}\text { RT-PCR/Western } \\
\text { blotting }\end{array}$ & (68) \\
\hline & $\begin{array}{l}\text { PMA-treated } \\
\text { THP-1 macrophages }\end{array}$ & $\begin{array}{l}\text { RT-PCR/Western } \\
\text { blotting }\end{array}$ & (68) \\
\hline & THP-1, Mono-Mac-6 cells & $\begin{array}{l}\text { RT-PCR/Western } \\
\text { blotting }\end{array}$ & (15) \\
\hline \multirow[t]{2}{*}{ YKL-39 } & $\begin{array}{l}\text { Human primary } \\
\text { monocyte-derived } \\
\text { macrophages stimulated } \\
\text { by TGF-beta and IL-4 }\end{array}$ & RT-PCR & $(33,69)$ \\
\hline & $\begin{array}{l}\text { Alternatively activated } \\
\text { microglia in Alzheimer's } \\
\text { disease patients }\end{array}$ & RT-PCR & (29) \\
\hline
\end{tabular}

The secretion of SI-CLP and YKL-39 at least partially depends on their transport into the secretory lysosomes, mediated by their intracellular sorting by stabilin-1 $(15,33)$. Lysosomes are organelles with complex functions involved in the cell death, immunity, signaling, and stress responses (71-73) that not only participate in digesting extracellular material internalized by endocytosis and intracellular components sequestered by autophagy but also secrete their contents by fusing with the plasma membrane (72). Two types of lysosome-contained proteins are necessary for their functions: soluble hydrolases and integral lysosomal membrane proteins. More than 60 hydrolases have been identified and characterized, some of which play an important role in tumor progression $(72,74)$. The best investigated lysosomal hydrolases are the cathepsin proteases, 
which are subdivided into three groups based on the active site of the amino acids and the catalytic activity: serine cathepsins (cathepsins A and G), cysteine cathepsins (cathepsins B, C, F, and $\mathrm{H}$ ), and aspartic cathepsins (cathepsins D and E) (72). It has been suggested that cathepsins could either promote or suppress tumor growth; the cytosolic cathepsins inhibit tumor growth by activating the apoptotic pathway (75), whereas, in contrast, the extracellular cathepsins promote tumor growth through degradation of basement membrane and activation of other pro-tumorigenic proteins (76). Cathepsins B and $\mathrm{E}$ have been proved to be involved in cancer progression and metastasis in different types of cancer, such as breast cancer and pancreatic cancer $(69,77)$. Glyco_18 domaincontaining proteins were also found by us and others to be sorted via the endosomal/lysosomal system and secreted by activated macrophages $(4,15,78)$. Chitotriosidase was seen to be comparable to cathepsin $\mathrm{D}$ in lysosomal vesicles in macrophages (78). We identified that LAMP+CD63+lysosomes are major sites of SI-CLP localization in human IL4 and dexamethasone-stimulated M2 macrophages (15). Sorting of newly synthesized SI-CLP from the biosynthetic to the lysosomal pathway was mediated by stabilin-1. Similarly, we found that YKL-39 is sorted into LAMP-1 positive and secretioncommitted CD63 positive lysosomes in human IL-4+TGF-betastimulated macrophages (33). The mechanistic role of stabilin1 in the intracellular sorting of YKL-39 was confirmed using the HEK293-YKL-39-FLAG cell line, where YKL-39 is misssorted into the globular structures and localized in the nuclear area. Transient overexpression of recombinant stabilin-1 in this model cell line resulted in the re-distribution of YKL39 into the cytoplasm, and this effect was similar to our previously published data demonstrating the role of stabilin1 in the intracellular sorting of SI-CLP in a H1299 cell model (15). Protein-protein interaction studies demonstrated that the extracellular fasciclin domain 7 domain of stabilin-1 directly interacts with SI-CLP and YKL-39 $(15,33)$. Therefore, YKL-39, similarly to SI-CLP, can be targeted by stabilin-1 into the lysosomal secretory pathway in human alternatively activated macrophages.

YKL-39 was identified by us to be produced by human macrophages in vitro and in the tumor microenvironment $(33,79)$. In vitro, TGFbeta was a key inducer of YKL39 gene expression, and release in primary macrophages propagated up to 24 days (33). During tumor growth and progression, a significant amount of TGF-beta is produced by cancer and stromal cells and secreted into the tumor microenvironment (80). Increased expression of TGF-beta was shown to correlate with the malignancy of different cancers $(81,82)$. Therefore, TGF-beta is considered to play a major role in the initiation and progression of cancer by affecting the proliferation, apoptosis, and differentiation of cancer cells in the tumor microenvironment (83). Using a monoclonal-aYKL-39 antibody generated by us, we have identified that in human breast cancer, YKL-39 is expressed on TAMs, but, in contrast to YKL-40, not on cancer cells.

\section{CHITINASE-LIKE PROTEINS IN CANCER}

Accumulating data reveals that CLPs play a role in the progression of different types of cancer. Elevated levels of circulating YKL-40 are related to poor outcome or short diseasefree survival in glioblastoma, melanoma, ovarian, breast, colon, lung, and prostate cancers in humans (52, 84-92). Moreover, in breast cancer, elevated serum levels of YKL-40 have been used as a prognostic biomarker (84). The adhesive and invasive abilities of U87MG glioblastoma cells were significantly inhibited when endogenous expression of YKL-40 was blocked (93). YKL-40 was also induced during pulmonary melanoma metastasis, and this induction was mediated by Sema7a $(90,94)$. Overexpression of YKL-40 and YM1/2 was observed in the pre-neoplastic phase of a latent membrane protein 1 (LMP1) viral oncogene-expressing transgenic mouse model, which is associated with carcinogenic progression (95). In breast cancer, YKL-40 may support cancer progression and facilitate angiogenesis, as experimental knockdown of YKL-40 in tumorigenic breast epithelial cell line D492HER2 resulted in reduced migration and invasion as well as reduced ability to induce angiogenesis in vitro (96). Targeting of YKL-40 as a potential therapeutic approach has been evaluated in melanoma and glioblastoma mouse models. Application of anti-YKL-40 antibody in the U87 glioblastoma mouse models resulted in the suppression of xenograft tumor growth as well as angiogenesis (97). However, an opposite result was seen in BALB/c-scid mice injected with human melanoma cells; the tumor growth was enhanced after anti-YKL-40 antibody treatment (98). The contradictory results between glioblastoma and melanoma mouse models can be explained by the different mouse strains and antibodies used in the studies.

SI-CLP was shown to induce the secretion of IL-1 $\beta$, IL6, IL-12, and IL-13 in PMA-treated THP-1 cells, suggesting that it may serve as a regulator of inflammation and in the tumor microenvironment (68). The regulatory effect of SI-CLP is not clear yet since the cytokines induced by SI-CLP can either promote (IL-1 $\beta$, IL-6, IL-13) or suppress (IL-12) tumor progression $(99,100)$.

Information about the potential role of YKL-39 in cancer is still very limited. Serial Analysis of Gene Expression (SAGE) revealed that YKL-39 expression is elevated in the II-IV grades of glial tumors (101). The expression of YKL-39 was detected in the majority of glioblastomas (19 of 27 samples analyzed) by Northern blot analysis and demonstrated on the protein level by Western blotting (102). Our recent study has demonstrated that YKL-39 is expressed in human breast cancer, and its expression level were indicative of metastatic spread in patients who underwent neoadjuvant chemotherapy, as discussed below.

\section{CHEMOTHERAPY, TAMS AND CHITINASE-LIKE PROTEINS}

Chemotherapy (CT) is a common strategy for reducing tumor size and aggressiveness before surgical intervention (103). However, only a subset of patients respond efficiently to neoajuvant chemotherapy (NAC). Chemoresistance and 
chemotherapy-induced immunosuppression can result in the relapse of tumors and are critical for survival in cancer patients $(49,104)$. Numerous studies have examined the molecular mechanisms that promote the chemoresistance of cancer cells, such as the induction of anti-apoptotic regulators, $\mathrm{ABC}$ transporters, aberrant transcription factor nuclear factor- $\kappa \mathrm{B}(\mathrm{NF}-\kappa \mathrm{B})$ activity, and the mechanisms of damaged DNA repair (104-106). Evidence is accumulating that the tumor microenvironment, and TAMs in particular, is critical to the response to chemotherapy $(107,108)$. TAMs may contribute to resistance to therapy and facilitate tumor progression via macrophage-induced suppression of $\mathrm{T}$ cell immunity, maintenance of tumor cell survival, and stimulation of tumor revascularization $(50,108,109)$. Chemotherapeutic agents can edit macrophages in tumor-protective or antitumor directions, where three major mechanisms must be considered: (1) changes in the macrophage phenotype; (2) induced recruitment of monocytes or macrophages to the tumor site; and (3) systemic depletion of monocytes/macrophages (110). Numerous data demonstrate that chemotherapy interacts with macrophages; however, the mechanisms of the direct action of chemotherapeutic drugs on TAMs, as well as the mechanisms of TAM-mediated chemoresistance in tumors, still require in-depth investigation. The profile of immune cell subpopulations in the tumor microenvironment can help to identify a group of patients that are more sensitive/or resistant to neoadjuvant chemotherapy to improve treatment regimens.

Several studies have identified correlations between levels of CLPs and the efficiency of chemotherapy. For example, a high plasma level of YKL-40 was associated with shorter progression-free survival (PFS) and shorter overall survival (OS) in 140 patients with chemotherapy-resistant ovarian cancer treated with bevacizumab (111). A similar result was obtained in prostate cancer, where high serum YKL-40 levels were associated with shorter OS and disease-specific survival (DSS) in 109 patients who received first-line treatment with docetaxel (DOC). Moreover, YKL-40 serum levels were significantly higher in DOC-resistant patients (112). In another study, 120 patients with small cell lung cancer with high levels of serum YKL40 had a shorter PFS and OS than those with low levels of serum YKL-40 (113). YKL-40 levels were significantly decreased after chemotherapy (cisplatin with etoposide or cisplatin with irinotecan). However, patients with high serum YKL-40 showed a poorer response to chemotherapy than those patients with low serum YKL-40. Of the 81 patients with high serum YKL40 , only $46 \%$ responded to chemotherapy with either complete response or partial remission. Of 39 patients who had low serum YKL-40, 70\% exhibited a response to chemotherapy $(p=0.031)$

\section{REFERENCES}

1. Boot RG, van Achterberg TA, van Aken BE, Renkema GH, Jacobs MJ, Aerts JM, et al. Strong induction of members of the chitinase family of proteins in atherosclerosis. Arterioscler Thromb Vasc Biol. (1999) 19:687-94. doi: 10.1161/01.ATV.19.3.687
(113). The question of the exact role of CLPs in the response of cancer cells, macrophages, and the intratumoral vasculature to chemotherapeutic agents remains open.

A recent study of 195 patients in the European cohort with pancreatic ductal adenocarcinoma indicated singlenucleotide polymorphisms (SNP) in YKL39 that was associated with tumor-associated survival after pancreatic resection. Individuals who were homozygous for the minor A allele of SNP rs684559 (YKL-39) had an increased risk for tumorassociated death compared with patients with at least $1 \mathrm{G}$ allele of rs684559 (protective phenotype) (114). Our recent study for the first time demonstrated the prognostic role of YKL-39 in cancer metastasis in breast cancer patients after neoadjuvant therapy (33). In patients with metastases, the expression levels of YKL-39 in tumor tissue obtained after NAC were more than 6 times higher than in the patients without metastases. Significantly higher expression levels of YKL-39 were found in patients with stable disease or progressive disease than in patients with the objective response (partial response). Our data demonstrated that elevated levels of YKL-39 in tumor tissues after NAC are indicative of poor prognosis.

Taking into consideration that YKL-39 was demonstrated by us as a pro-angiogenic factor and chemoattractant for monocytes, we suggest that YKL-39 is a promising target for cancer therapy and that targeting of YKL-39 can be considered in combination with NAC in breast cancer patients in order to reduce the risk of metastasis formation.

\section{AUTHOR CONTRIBUTIONS}

JK has structured the article, analyzed the literature, and wrote the manuscript. IL has analyzed the literature and wrote the manuscript. TL has analyzed the literature and wrote the manuscript.

\section{FUNDING}

This work was supported by the Russian Scientific Foundation, grant \#19-15-00151.

\section{ACKNOWLEDGMENTS}

Part of this work was published as the Ph.D. Thesis of TL, performed at the University of Heidelberg, Medical Faculty Mannheim, Institute of Transfusion Medicine and Immunology, which is available online at http://www.ub.uni-heidelberg.de/ archiv/23511 (115).
2. Di Rosa M, Distefano G, Zorena K, Malaguarnera L. Chitinases and immunity: ancestral molecules with new functions. Immunobiology. (2016) 221:399-411. doi: 10.1016/j.imbio.2015.11.014

3. Tharanathan RN, Kittur FS. Chitin-the undisputed biomolecule of great potential. Crit Rev Food Sci Nutr. (2003) 43:61-87. doi: $10.1080 / 10408690390826455$ 
4. Kzhyshkowska J, Gratchev A, Goerdt S. Human chitinases and chitinase-like proteins as indicators for inflammation and cancer. Biomark Insights. (2007) 2:128-46. doi: 10.1177/117727190700200023

5. Muzzarelli RA. Chitin: Oxford, UK: Pergamon Press (1977).

6. Elias JA, Homer RJ, Hamid Q, Lee CG. Chitinases and chitinase-like proteins in T H 2 inflammation and asthma. J Allergy Clin Immunol. (2005) 116:497500. doi: 10.1016/j.jaci.2005.06.028

7. Mondal S, Baksi S, Koris A, Vatai G. Journey of enzymes in entomopathogenic fungi. Pac Sci Rev A Nat Sci Eng. (2016) 18:85-99. doi: 10.1016/j.psra.2016.10.001

8. Donnelly LE, Barnes PJ. Acidic mammalian chitinase-a potential target for asthma therapy. Trends Pharmacol Sci. (2004) 25:509-11. doi: 10.1016/j.tips.2004.08.002

9. Zhu Z, Zheng T, Homer RJ, Kim Y-K, Chen NY, Cohn L, et al. Acidic mammalian chitinase in asthmatic Th2 inflammation and IL-13 pathway activation. Science. (2004) 304:1678-82. doi: 10.1126/science.1095336

10. Cox T. Gaucher disease: understanding the molecular pathogenesis of sphingolipidoses. J Inherit Metab Dis. (2001) 24:106-21. doi: 10.1023/a:1012496514170

11. Raskovalova T, Deegan PB, Yang R, Pavlova E, Stirnemann J, Labarère J, et al. Plasma chitotriosidase activity versus CCL18 level for assessing type I Gaucher disease severity: protocol for a systematic review with meta-analysis of individual participant data. Syst Rev. (2017) 6:87. doi: 10.1186/s13643-017-0483-x

12. Kzhyshkowska J, Yin S, Liu T, Riabov V, Mitrofanova I. Role of chitinase-like proteins in cancer. Biol Chem. (2016) 397:231-47. doi: 10.1515/hsz-2015-0269

13. Volck B, Price PA, Johansen JS, Sørensen O, Benfield TL, Nielsen HJ, et al. YKL-40, a mammalian member of the chitinase family, is a matrix protein of specific granules in human neutrophils. Proc Assoc Am Phys. (1998) 110:35160.

14. Hu B, Trinh K, Figueira WF, Price PA. Isolation and sequence of a novel human chondrocyte protein related to mammalian members of the chitinase protein family. J Biol Chem. (1996) 271:19415-20. doi: $10.1074 /$ jbc.271.32.19415

15. Kzhyshkowska J, Mamidi S, Gratchev A, Kremmer E, Schmuttermaier C, Krusell L, et al. Novel stabilin-1 interacting chitinase-like protein (SI-CLP) is up-regulated in alternatively activated macrophages and secreted via lysosomal pathway. Blood. (2006) 107 3221-3228. doi: 10.1182/blood-2005-07-2843

16. Jin H, Copeland N, Gilbert D, Jenkins N, Kirkpatrick R, Rosenberg M. Genetic characterization of the murine Yml gene and identification of a cluster of highly homologous genes. Genomics. (1996) 54 316-322. doi: 10.1006/geno.1998.5593

17. Schimpl M, Rush CL, Betou M, Eggleston IM, Recklies AD, Van Aalten DM. Human YKL-39 is a pseudo-chitinase with retained chitooligosaccharidebinding properties. Biochem J. (2012) 446:149-57. doi: 10.1042/ BJ20120377

18. Ranok A, Wongsantichon J, Robinson RC, Suginta W. Structural and thermodynamic insights into chitooligosaccharide binding to human cartilage chitinase 3-like protein 2 (CHI3L2 or YKL-39). J Biol Chem. (2015) 290:2617-29. doi: 10.1074/jbc.M114.588905

19. Bigg HF, Wait R, Rowan AD, Cawston TE. The mammalian chitinaselike lectin, YKL-40, binds specifically to type I collagen and modulates the rate of type I collagen fibril formation. J Biol Chem. (2006) 281:21082-95. doi: 10.1074/jbc.M601153200

20. Fusetti F, Pijning T, Kalk KH, Bos E, Dijkstra BW. Crystal structure and carbohydrate-binding properties of the human cartilage glycoprotein-39. J Biol Chem. (2003)278:37753-60. doi: 10.1074/jbc.M303137200

21. Renkema GH, Boot RG, Au FL, Donker-Koopman WE, Strijland A, Muijsers AO. Chitotriosidase, a chitinase, and the $39-\mathrm{kDa}$ human cartilage glycoprotein, a chitin-binding lectin, are homologues of family 18 glycosyl hydrolases secreted by human macrophages. Eur J Biochem. (1998) 251:5049. doi: 10.1046/j.1432-1327.1998.2510504.x

22. Nishikawa KC, Millis AJ (2003). gp38k (CHI3L1) is a novel adhesion and migration factor for vascular cells. Exp Cell Res. (2003) 287:79-87. doi: 10.1016/S0014-4827(03)00069-7
23. Meng G, Zhao Y, Bai X, Liu Y, Green TJ, Luo M, et al. Structure of human stabilin-1 interacting chitinase-like protein (SI-CLP) reveals a saccharidebinding cleft with lower sugar-binding selectivity. J Biol Chem. (2010) 285:39898-904. doi: 10.1074/jbc.M110.130781

24. Chang N-CA, Hung S-I, Hwa K-Y, Kato I, Chen J-E, Liu C-H, et al. A macrophage protein, Yml, transiently expressed during inflammation is a novel mammalian lectin. J Biol Chem. (2001) 276:17497-506. doi: 10.1074/jbc.M010417200

25. Francescone RA, Scully S, Faibish M, Taylor SL, Oh D, Moral L, et al. Role of YKL-40 in the angiogenesis, radioresistance, and progression of glioblastoma. J Biol Chem. (2011) 286:15332-43. doi: $10.1074 /$ jbc.M110.212514

26. Shao R, Hamel K, Petersen L, Cao Q, Arenas RB, Bigelow C, et al. YKL40 , a secreted glycoprotein, promotes tumor angiogenesis. Oncogene. (2009) 28:4456-68. doi: 10.1038/onc.2009.292

27. Knorr T, Obermayr F, Bartnik E, Zien A, Aigner T. YKL-39 (chitinase 3-like protein 2), but not YKL-40 (chitinase 3-like protein 1), is up regulated in osteoarthritic chondrocytes. Ann Rheum Dis. (2003) 62:995-8. doi: 10.1136/ard.62.10.995

28. Steck E, Breit S, Breusch SJ, Axt M, Richter W. Enhanced expression of the human chitinase 3-like 2 gene (YKL-39) but not chitinase 3-like 1 gene (YKL-40) in osteoarthritic cartilage. Biochem Biophys Res Commun. (2002) 299:109-15. doi: 10.1016/S0006-291X(02)02585-8

29. Colton CA, Mott RT, Sharpe H, Xu Q, Van Nostrand WE, Vitek MP. Expression profiles for macrophage alternative activation genes in $\mathrm{AD}$ and in mouse models of AD. J Neuroinflammation. (2006) 3:27. doi: 10.1186/1742-2094-3-27

30. Hinsinger G, Galéotti N, Nabholz N, Urbach S, Rigau V, Demattei C, et al. Chitinase 3-like proteins as diagnostic and prognostic biomarkers of multiple sclerosis. Mult Scler. (2015) 21:1251-61. doi: 10.1177/1352458514561906

31. Møllgaard M, Degn M, Sellebjerg F, Frederiksen J, Modvig S. Cerebrospinal fluid chitinase-3-like 2 and chitotriosidase are potential prognostic biomarkers in early multiple sclerosis. Eur J Neurol. (2016) 23:898-905. doi: $10.1111 /$ ene. 12960

32. Sanfilippo C, Nunnari G, Calcagno A, Malaguarnera L, Blennow K, Zetterberg $\mathrm{H}$, et al. The chitinases expression is related to Simian Immunodeficiency Virus Encephalitis (SIVE) and in HIV encephalitis (HIVE). Virus Res. (2017) 227:220-30. doi: 10.1016/j.virusres.2016.10.012

33. Liu T, Larionova I, Litviakov N, Riabov V, Zavyalova M, Tsyganov M, et al. Tumor-associated macrophages in human breast cancer produce new monocyte attracting and pro-angiogenic factor YKL-39 indicative for increased metastasis after neoadjuvant chemotherapy. Oncoimmunology. (2018) 7:e1436922. doi: 10.1080/2162402X.2018.1436922

34. Owhashi M, Arita H, Hayai N. Identification of a novel eosinophil chemotactic cytokine (ECF-L) as a chitinase family protein. J Biol Chem. (2000) 275:1279-86. doi: 10.1074/jbc.275.2.1279

35. Zhao J, Lv Z, Wang F, Wei J, Zhang Q, Li S, et al. Ym1, an eosinophilic chemotactic factor, participates in the brain inflammation induced by Angiostrongylus cantonensis in mice. Parasitol Res. (2013) 112:2689-95. doi: 10.1007/s00436-013-3436-x

36. HogenEsch H, Dunham A, Seymour R, Renninger M, Sundberg JP. Expression of chitinase-like proteins in the skin of chronic proliferative dermatitis (cpdm/cpdm) mice. Exp Dermatol. (2006) 15:808-14. doi: 10.1111/j.1600-0625.2006.00483.x

37. Kawada M, Seno H, Kanda K, Nakanishi Y, Akitake R, Komekado H, et al. Chitinase 3-like 1 promotes macrophage recruitment and angiogenesis in colorectal cancer. Oncogene. (2012) 31:3111-23. doi: 10.1038/onc.2011.498

38. Tang H, Sun Y, Shi Z, Huang H, Fang Z, Chen J, et al. YKL-40 induces IL-8 expression from bronchial epithelium via MAPK (JNK and ERK) and NF-кB pathways, causing bronchial smooth muscle proliferation and migration. $J$ Immunol. (2013) 190:438-46. doi: 10.4049/jimmunol.1201827

39. Conrozier T, Carlier M, Mathieu P, Colson F, Debard A, Richard S, et al. Serum levels of YKL-40 and C reactive protein in patients with hip osteoarthritis and healthy subjects: a cross sectional study. Ann Rheum Dis. (2000) 59:828-31. doi: 10.1136/ard.59.10.828

40. Quail DF, Joyce JA. Microenvironmental regulation of tumor progression and metastasis. Nat Med. (2013) 19:1423-37. doi: 10.1038/nm.3394 
41. Riabov V, Gudima A, Wang N, Mickley A, Orekhov A, Kzhyshkowska J. Role of tumor associated macrophages in tumor angiogenesis and lymphangiogenesis. Front Physiol. (2014) 5:75. doi: 10.3389/fphys.2014.00075

42. Lin EY, Pollard JW. Tumor-associated macrophages press the angiogenic switch in breast cancer. Cancer Res. (2007) 67:5064-6. doi: 10.1158/0008-5472.CAN-07-0912

43. Nishida N, Yano H, Nishida T, Kamura T, Kojiro M. Angiogenesis in cancer. Vasc Health Risk Manag. (2006) 2:213-9. doi: 10.2147/vhrm.2006.2.3.213

44. Casazza A, Di Conza G, Wenes M, Finisguerra V, Deschoemaeker S, Mazzone M. Tumor stroma: a complexity dictated by the hypoxic tumor microenvironment. Oncogene. (2014) 33:1743-54. doi: 10.1038/onc.2013.121

45. Rosen LS. VEGF-targeted therapy: therapeutic potential and recent advances. Oncologist. (2005) 10:382-91. doi: 10.1634/theoncologist.10-6-382

46. Chelariu-Raicu A, Coleman RL, Sood AK. Anti-angiogenesis therapy in ovarian cancer: which patient is it most likely to benefit? Oncology. (2019) 33:629378.

47. Hurwitz H, Fehrenbacher L, Novotny W, Cartwright T, Hainsworth J, Heim W, et al. Bevacizumab plus irinotecan, fluorouracil, and leucovorin for metastatic colorectal cancer. N Engl J Med. (2004) 350:2335-42. doi: 10.1056/NEJMoa032691

48. Johnson DH, Fehrenbacher L, Novotny WF, Herbst RS, Nemunaitis JJ, Jablons DM, et al. Randomized phase II trial comparing bevacizumab plus carboplatin and paclitaxel with carboplatin and paclitaxel alone in previously untreated locally advanced or metastatic non-small-cell lung cancer. J Clin Oncol. (2004) 22:2184-91. doi: 10.1200/JCO.2004.11.022

49. Dalton HJ, Pradeep S, McGuire M, Hailemichael Y, Ma S, Lyons $\mathrm{Y}$, et al. Macrophages facilitate resistance to anti-VEGF therapy by altered VEGFR expression. Clin Cancer Res. (2017) 23:7034-46. doi: 10.1158/1078-0432.CCR-17-0647

50. Hughes R, Qian BZ, Rowan C, Muthana M, Keklikoglou I, Olson OC, et al. Perivascular M2 macrophages stimulate tumor relapse after chemotherapy. Cancer Res. (2015) 75:3479-91. doi: 10.1158/0008-5472.CAN-14-3587

51. De Palma M, Lewis CE. Macrophages limit chemotherapy. Cancer Discov. (2011) 1:54-67. doi: 10.1038/472303a

52. Shao R. YKL- 40 acts as an angiogenic factor to promote tumor angiogenesis. Front Physiol. (2013) 4:122. doi: 10.3389/fphys.2013.00122

53. Shao R, Cao Q, Arenas R, Bigelow C, Bentley B, Yan W. Breast cancer expression of YKL-40 correlates with tumour grade, poor differentiation, and other cancer markers. Br J Cancer. (2011) 105:1203-9. doi: 10.1038/bjc.2011.347

54. Saidi A, Javerzat S, Bellahcene A, De Vos J, Bello L, Castronovo V, et al. Experimental anti-angiogenesis causes upregulation of genes associated with poor survival in glioblastoma. Int J Cancer. (2008) 122:2187-98. doi: $10.1002 /$ ijc. 23313

55. Kzhyshkowska J, Neyen C, Gordon S. Role of macrophage scavenger receptors in atherosclerosis. Immunobiology. (2012) 217:492-502. doi: 10.1016/j.imbio.2012.02.015

56. Oishi Y, Manabe I. Macrophages in age-related chronic inflammatory diseases. NPJ Aging Mech Dis. (2016) 2:16018. doi: 10.1038/npjamd.2016.18

57. Dehne N, Mora J, Namgaladze D, Weigert A, Brüne B. Cancer cell and macrophage cross-talk in the tumor microenvironment. Curr Opin Pharmacol. (2017) 35:12-19. doi: 10.1016/j.coph.2017.04.007

58. Goswami KK, Ghosh T, Ghosh S, Sarkar M, Bose A, Baral R. Tumor promoting role of anti-tumor macrophages in tumor microenvironment. Cell Immunol. (2017) 316:1-10. doi: 10.1016/j.cellimm.2017.04.005

59. Gisterå A, Hansson GK. The immunology of atherosclerosis. Nat Rev Nephrol. (2017) 13:368-80. doi: 10.1038/nrneph.2017.51

60. Rhee I. Diverse macrophages polarization in tumor microenvironment. Arch Pharm Res. (2016) 39:1588-96. doi: 10.1007/s12272-016-0820-y

61. Franklin RA, Li MO. Ontogeny of tumor-associated macrophages and its implication in cancer regulation. Trends Cancer. (2016) 2:20-34. doi: 10.1016/j.trecan.2015.11.004

62. Raggi F, Pelassa S, Pierobon D, Penco F, Gattorno M, Novelli F, et al. Regulation of human macrophage M1-M2 polarization balance by hypoxia and the triggering receptor expressed on myeloid cells-1. Front Immunol. (2017) 8:1097. doi: 10.3389/fimmu.2017.01097
63. Junker N, Johansen JS, Andersen CB, Kristjansen PE. Expression of YKL-40 by peritumoral macrophages in human small cell lung cancer. Lung Cancer. (2005) 48:223-31. doi: 10.1016/j.lungcan.2004. 11.011

64. Johansen JS, Milman N, Hansen M, Garbarsch C, Price PA, Graudal N. Increased serum YKL-40 in patients with pulmonary sarcoidosisa potential marker of disease activity? Respir Med. (2005) 99:396-402. doi: 10.1016/j.rmed.2004.09.016

65. Kunz L, van't Wout E, van Schadewijk A, Postma D, Kerstjens H, Sterk P, et al. Regulation of YKL-40 expression by corticosteroids: effect on proinflammatory macrophages in vitro and its modulation in COPD in vivo. Respir Res. (2015) 16:154. doi: 10.1186/s12931-015-0314-3

66. Sohn MH, Kang MJ, Matsuura H, Bhandari V, Chen NY, Lee CG, et al. The chitinase-like proteins breast regression protein-39 and YKL-40 regulate hyperoxia-induced acute lung injury. Am J Respir Crit Care Med. (2010) 182:918-28. doi: 10.1164/rccm.200912-1793OC

67. Di Rosa M, Malaguarnera G, De Gregorio C, Drago F, Malaguarnera L. Evaluation of CHI3L-1 and CHIT-1 expression in differentiated and polarized macrophages. Inflammation. (2013) 36:482-92. doi: 10.1007/s10753-012-9569-8

68. Xiao W, Meng G, Zhao Y, Yuan H, Li T, Peng Y, et al. Human secreted stabilin-1-interacting chitinase-like protein aggravates the inflammation associated with rheumatoid arthritis and is a potential macrophage inflammatory regulator in rodents. Arthritis Rheumatol. (2014) 66:1141-52. doi: 10.1002/art.38356

69. Keliher EJ, Reiner T, Earley S, Klubnick J, Tassa C, Lee AJ, et al. Targeting cathepsin $\mathrm{E}$ in pancreatic cancer by a small molecule allows in vivo detection. Neoplasia. (2013) 15:684-93. doi: 10.1593/neo.13276

70. Rehli M, Nille H-H, Ammon C, Langmann S, Schwarzfischer L, Andreesen $\mathrm{R}$, et al. Transcriptional regulation of $\mathrm{CHI} 3 \mathrm{~L} 1$, a marker gene for late stages of macrophage differentiation. J Biol Chem. (2003) 278:44058-67. doi: 10.1074/jbc.M306792200

71. Appelqvist $\mathrm{H}$, Wäster $\mathrm{P}$, Kågedal $\mathrm{K}$, Öllinger $\mathrm{K}$. The lysosome: from waste bag to potential therapeutic target. J Mol Cell Biol. (2013) 5:214-26. doi: $10.1093 / \mathrm{jmcb} / \mathrm{mjt} 022$

72. Piao S, Amaravadi RK. Targeting the lysosome in cancer. Ann N Y Acad Sci. (2016) 1371:45-54. doi: 10.1111/nyas.12953

73. Wartosch L, Bright NA, Luzio JP. Lysosomes. Curr Biol. (2015) 25:R315-6. doi: 10.1016/j.cub.2015.02.027

74. Schröder BA, Wrocklage C, Hasilik A, Saftig P. The proteome of lysosomes. Proteomics. (2010) 10:4053-76. doi: 10.1002/pmic.201000196

75. Olson OC, Joyce JA. Cysteine cathepsin proteases: regulators of cancer progression and therapeutic response. Nat Rev Cancer. (2015) 15:712-29. doi: $10.1038 / \mathrm{nrc} 4027$

76. Repnik U, Stoka V, Turk V, Turk B. Lysosomes and lysosomal cathepsins in cell death. Biochim Biophys Acta. (2012) 1824:22-33. doi: 10.1016/j.bbapap.2011.08.016

77. Bengsch F, Buck A, Günther S, Seiz J, Tacke M, Pfeifer D, et al. Cell type-dependent pathogenic functions of overexpressed human cathepsin $\mathrm{B}$ in murine breast cancer progression. Oncogene. (2014) 33:4474-84. doi: 10.1038/onc.2013.395

78. Renkema GH, Boot RG, Strijland A, Donker-Koopman WE, Berg M, Muijsers AO, et al. Synthesis, sorting, and processing into distinct isoforms of human macrophage chitotriosidase. Eur J Biochem. (1997) 244:279-85. doi: 10.1111/j.1432-1033.1997.00279.x

79. Gratchev A, Schmuttermaier C, Mamidi S, Gooi L, Goerdt S, Kzhyshkowska J. Expression of osteoarthritis marker YKL-39 is stimulated by transforming growth factor beta (TGF-beta) and IL-4 in differentiating macrophages. Biomark Insights. (2008) 3:39-44. doi: 10.1177/117727190800300003

80. Pickup M, Novitskiy S, Moses HL. The roles of TGF beta in the tumour microenvironment. Nat Rev Cancer. (2013) 13:788-99. doi: 10.1038/nrc3603

81. Derynck R, Akhurst RJ, Balmain A. TGF- $\beta$ signaling in tumor suppression and cancer progression. Nat Genet. (2001) 29:117-29. doi: 10.1038/ng1001-117

82. Katsuno Y, Lamouille S, Derynck R. TGF- $\beta$ signaling and epithelialmesenchymal transition in cancer progression. Curr Opin Oncol. (2013) 25:76-84. doi: 10.1097/CCO.0b013e32835b6371 
83. Cantelli G, Crosas-Molist E, Georgouli M, Sanz-Moreno V. TGFbinduced transcription in cancer. Semin Cancer Biol. (2017) 42:60-9. doi: 10.1016/j.semcancer.2016.08.009

84. Cintin C, Johansen J, Christensen IJ, Price P, Sørensen S, Nielsen HJ. Serum YKL-40 and colorectal cancer. Br J Cancer. (1999) 79:1494-9. doi: 10.1038/sj.bjc.6690238

85. Høgdall EV, Ringsholt M, Høgdall CK, Christensen IJ, Johansen JS, Kjaer SK, et al. YKL-40 tissue expression and plasma levels in patients with ovarian cancer. BMC Cancer. (2009) 9:8. doi: 10.1186/1471-2407-9-8

86. Hormigo A, Gu B, Karimi S, Riedel E, Panageas KS, Edgar MA, et al. YKL-40 and matrix metalloproteinase- 9 as potential serum biomarkers for patients with high-grade gliomas. Clin Cancer Res. (2006) 12:5698-704. doi: 10.1158/1078-0432.CCR-06-0181

87. Iwamoto FM, Hottinger AF, Karimi S, Riedel E, Dantis J, Jahdi M, et al. Serum YKL-40 is a marker of prognosis and disease status in high-grade gliomas. Neuro Oncol. (2011) 13:1244-51. doi: 10.1093/neuonc/nor117

88. Johansen JS, Brasso K, Iversen P, Teisner B, Garnero P, Price PA, et al. Changes of biochemical markers of bone turnover and YKL-40 following hormonal treatment for metastatic prostate cancer are related to survival. Clin Cancer Res. (2007) 13:3244-9. doi: 10.1158/1078-0432.CCR-06-2616

89. Libreros S, Iragavarapu-Charyulu V. YKL-40/CHI3L1 drives inflammation on the road of tumor progression. J Leukoc Biol. (2015) 98:931-6. doi: 10.1189/jlb.3VMR0415-142R

90. Ma B, Herzog EL, Lee CG, Peng X, Lee C-M, Chen X, et al. Role of chitinase 3-like-1 and semaphorin 7a in pulmonary melanoma metastasis. Cancer Res. (2015) 75:487-96. doi: 10.1158/0008-5472.CAN-13-3339

91. Schmidt H, Johansen JS, Gehl J, Geertsen PF, Fode K, von der Maase H. Elevated serum level of YKL-40 is an independent prognostic factor for poor survival in patients with metastatic melanoma. Cancer. (2006) 106:1130-9. doi: $10.1002 / \mathrm{cncr} .21678$

92. Wan G, Xiang L, Sun X, Wang X, Li H, Ge W, et al. Elevated YKL-40 expression is associated with a poor prognosis in breast cancer patients. Oncotarget. (2017) 8:5382-91. doi: 10.18632/oncotarget.14280

93. Ku BM, Lee YK, Ryu J, Jeong JY, Choi J, Eun KM, et al. CHI3L1 (YKL-40) is expressed in human gliomas and regulates the invasion, growth and survival of glioma cells. Int J Cancer. (2011) 128:1316-26. doi: 10.1002/ijc.25466

94. He CH, Lee CG, Cruz CSD, Lee C-M, Zhou Y, Ahangari F, et al. Chitinase 3like 1 regulates cellular and tissue responses via IL-13 receptor $\alpha 2$. Cell Rep. (2013) 4:830-41. doi: 10.1016/j.celrep.2013.07.032

95. Qureshi AM, Hannigan A, Campbell D, Nixon C, Wilson JB. Chitinaselike proteins are autoantigens in a model of inflammation-promoted incipient neoplasia. Genes Cancer. (2011) 2:74-87. doi: 10.1177/194760191 1402681

96. Morera E, Steinhäuser SS, Budkova Z, Ingthorsson S, Kricker J, Krueger A, et al. YKL-40/CHI3L1 facilitates migration and invasion in HER2 overexpressing breast epithelial progenitor cells and generates a niche for capillary-like network formation. In Vitro Cell Dev Biol Anim. (2019) 55:83853. doi: 10.1007/s11626-019-00403-x

97. Faibish M, Francescone R, Bentley B, Yan W, Shao R. A YKL-40neutralizing antibody blocks tumor angiogenesis and progression: a potential therapeutic agent in cancers. Mol Cancer Ther. (2011) 10:742-51. doi: 10.1158/1535-7163.MCT-10-0868

98. Salamon J, Hoffmann T, Elies E, Peldschus K, Johansen JS, Lüers G, et al. Antibody directed against human YKL-40 increases tumor volume in a human melanoma xenograft model in scid mice. PLoS ONE. (2014) 9:e95822. doi: 10.1371/journal.pone.0095822

99. Fujisawa T, Joshi BH, Puri RK. IL-13 regulates cancer invasion and metastasis through IL-13R $\alpha 2$ via ERK/AP-1 pathway in mouse model of human ovarian cancer. Int J Cancer. (2012) 131:344-56. doi: 10.1002/ijc. 26366

100. Voronov E, Dotan S, Krelin Y, Song X, Elkabets M, Carmi Y, et al. Unique versus redundant functions of IL- $1 \alpha$ and IL-1 $\beta$ in the tumor microenvironment. Front Immunol. (2013) 4:177. doi: $10.3389 /$ fimmu.2013.00177
101. Kavsan V, Shostak K, Dmitrenko V, Zozulya Y, Rozumenko V, Demotes-Mainard J. Characterization of genes with increased expression in human glioblastomas. Tsitol Genet. (2005) 39:37-49. doi: 10.1016/j.canlet.2004.07.001

102. Kavsan V, Dmitrenko V, Boyko O, Filonenko V, Avdeev S, Areshkov P, et al. Overexpression of YKL-39 gene in glial brain tumors. Scholarly Res Exchange. (2008) 2008:814849. doi: 10.3814/2008/814849

103. Rubovszky G, Horváth Z. Recent advances in the neoadjuvant treatment of breast cancer. J Breast Cancer. (2017) 20:119-31. doi: 10.4048/jbc.2017.20.2.119

104. Baghdadi M, Wada H, Nakanishi S, Abe H, Han N, Putra WE, et al. Chemotherapy-induced IL-34 enhances immunosuppression by tumorassociated macrophages and mediates survival of chemoresistant lung cancer cells. J Clin Pathol. (2012) 65:159-63. doi: 10.1158/0008-5472.CAN-16-1170

105. Harrison DJ. Molecular mechanisms of drug resistance in tumours. J Pathol. (1995) 175:7-12. doi: 10.1002/path.1711750103

106. Gottesman MM, Fojo T, Bates SE. Multidrug resistance in cancer: role of ATP-dependent transporters. Nat Rev Cancer. (2002) 2:48. doi: $10.1038 / \operatorname{nrc7} 06$

107. Noy R, Pollard JW. Tumor-associated macrophages: from mechanisms to therapy. Immunity. (2014) 41:49-61. doi: 10.1016/j.immuni.2014.09.021

108. Mantovani A, Allavena P. The interaction of anticancer therapies with tumor-associated macrophages. J Exp Med. (2015) 212:435-45. doi: 10.1084 /jem.20150295

109. Dijkgraaf EM, Heusinkveld M, Tummers B, Vogelpoel LTC, Goedemans $\mathrm{R}$, Jha $\mathrm{V}$, et al. Chemotherapy alters monocyte differentiation to favor generation of cancer-supporting M2 macrophages in the tumor microenvironment. Cancer Res. (2013) 73:2480-92. doi: 10.1158/0008-5472.CAN-12-3542

110. Larionova I, Cherdyntseva N, Liu T, Patysheva M, Rakina M, Kzhyshkowska J. Interaction of tumor-associated macrophages and cancer chemotherapy. Oncoimmunology. (2019) 8:1596004. doi: 10.1080/2162402X.2019.1596004

111. Boisen MK, Madsen CV, Dehlendorff C, Jakobsen A, Johansen JS, Steffensen KD. The prognostic value of plasma YKL-40 in patients with chemotherapyresistant ovarian cancer treated with bevacizumab. Int J Gynecol Cancer. (2016) 26:1390-8. doi: 10.1097/IGC.0000000000000798

112. Darr C, Krafft U, Hadaschik B, Tschirdewahn S, Sevcenco S, Csizmarik A, et al. The role of YKL-40 in predicting resistance to docetaxel chemotherapy in prostate cancer. Urol Int. (2018) 101:65-73. doi: 10.1159/000489891

113. $\mathrm{Xu} \mathrm{CH}, \mathrm{Yu}$ LK, Hao KK. Serum YKL-40 level is associated with the chemotherapy response and prognosis of patients with small cell lung cancer. PLoS ONE. (2014) 9:e96384. doi: 10.1371/journal.pone. 0096384

114. Dimitrakopoulos C, Vrugt B, Flury R, Schraml P, Knippschild U, Wild $\mathrm{P}$, et al. Identification and validation of a biomarker signature in patients with resectable pancreatic cancer via genome-wide screening for functional genetic variants. JAMA Surg. (2019) 154:e190484. doi: 10.1001/jamasurg.2019.0484

115. Liu T. Analysis of macrophage production and biological activity of chitinaselike protein YKL-39. Thesis. University of Heidelberg. Available online at: https://archiv.ub.uni-heidelberg.de/volltextserver/23511/

Conflict of Interest: The authors declare that the research was conducted in the absence of any commercial or financial relationships that could be construed as a potential conflict of interest.

Copyright (c) 2020 Kzhyshkowska, Larionova and Liu. This is an open-access article distributed under the terms of the Creative Commons Attribution License (CC BY). The use, distribution or reproduction in other forums is permitted, provided the original author(s) and the copyright owner(s) are credited and that the original publication in this journal is cited, in accordance with accepted academic practice. No use, distribution or reproduction is permitted which does not comply with these terms. 